\title{
FACTORS AFFECTING THE NATURAL ATTAINMENT OF PUBERTY IN THE GILT
}

\author{
P.E. HUGHES \\ Department of Animal Physiology and Nutrition, University of Leeds, UK
}

Puberty attainment in the gilt represents the onset of reproductive capability, since the first behavioural oestrus normally coincides with the pubertal ovulation. In the wild pig this first oestrus would occur in the late autumn when the gilt is approximately eight months of age (Signoret, 1980). However, in the domestic gilt the aim should be to stimulate the precocious attainment of puberty, the gilt being first mated, at second oestrus, at about 200 days of age.

It is both desirable and necessary to induce early puberty attainment in the gilt as she is a costly non-productive animal until the initiation of the first pregnancy. Thus, a review of the major factors influencing puberty attainment in the gilt is of value in identifying those measures which may be taken to reduce pubertal age and hence minimize the cost of introducing replacement gilts.

\section{Factors influencing puberty attainment}

\section{AGE, LIVEWEIGHT AND RATE OF GROWTH}

Several recent reviews have considered the relationship between puberty attainment and the age, liveweight and growth rate of the gilt (Hughes and Varley, 1980; Kirkwood, 1980). In each case the three factors were considered together as they are intimately related. In view of this it is difficult to dissociate the effects of each individual factor. Furthermore, in addition to having possible influences on puberty attainment themselves, they also reflect the effects of both genotype and nutrition. Thus, rather than review the effects of chronological age and livewieght on puberty attainment per se it is more useful to consider which of the two provides the more accurate reflection of the stage of development of the gilt. This measure of physiological development (often referred to as the physiological age) is used to assess the degree of maturity of the hypothalamicpituitary-ovarian axis, and hence the ability of the gilt to respond to puberty stimulation.

Many reports suggest that gilts normally attain puberty at approximately 200-210 days of age (Duncan and Lodge, 1960; Anderson and Melampy, 1972). However, since the range in age at puberty can be as wide as 102 


\section{Factors affecting the natural attainment of puberty in the gilt}

days (Aherne et al., 1976) to 350 days and above (Brooks and Smith, 1980) the average figure appears to be of little value. Equally, gilt liveweight at puberty is extremely variable, reported pubertal weights varying from 55 $\mathrm{kg}$ (Aherne et al., 1976) to over $120 \mathrm{~kg}$ (Hughes and Cole, 1975).

Despite this variability it has been reported repeatedly that chronological age is a more accurate indicator of degree of development than is liveweight (Robertson et al., 1951a; Robertson et al., 1951b; Duncan and Lodge, 1960; Hughes and Cole, 1976). It appears that the variability in gilt response to external stimuli (particularly boar contact) is greater at a constant liveweight than at a constant chronological age (Hughes and Cole, 1976).

There can be little doubt that many of the above data reflect the influences of many intrinsic and extrinsic factors, such as genotype, environment and boar contact, on puberty attainment. Nevertheless, they serve to illustrate the shortcomings of using either chronological age or liveweight as an indicator of a gilt's stage of development. Despite this, the consensus of opinion would appear to favour chronological age as the best available indicator of the physiological age of a.gilt. Indeed, most studies on the effects of imposed stimuli on puberty attainment in the gilt have used a constant chronological age as the starting point for the stimulation. If the consensus of opinion is correct then the implication is that, under conventional feeding systems, the influence of nutrition on puberty attainment is minimal-otherwise the liveweight of the gilt would provide the better measure of physiological development. However, although this latter point remains in doubt (see below) it is reasonable to suggest that there exists a lower liveweight threshold below which gilts will not achieve puberty (Dickerson, Gresham and McCance, 1964).

If liveweight does exert little influence on puberty attainment it might also be supposed that the rate of liveweight increase, or growth rate, would also have a minimal effect on the timing of puberty. Many reports do suggest that this is the case in the gilt (Burger, 1952; Haines, Warnick and Wallace, 1959; Gossett and Sorensen, 1959; Sorensen, Thomas and Gossett, 1961; Goode, Warnick and Wallace, 1965), although this is not necessarily true in all species (Brody, 1945; Monteiro and Falconer, 1966). Despite this conclusion Reutzel and Sumption (1968) have demonstrated that a positive genetic relationship exists between age and puberty and daily liveweight gain in the gilt. These data imply that, while genotype may influence puberty attainment, variations in growth rate of animals of similar genotype will have little effect on puberty.

\section{NUTRITION}

Whilst it has been shown that both liveweight and growth rate may, under normal conditions, exert little influence on puberty attainment in the gilt, it must be emphasized that this conclusion is rather tenuous. Since both factors may reflect the nutrient supply to the animal it may be easier to reach more positive conclusions through studying the effects of variations in feed supply on puberty attainment. Thus, the relationships between the attainment of puberty and both plane of feeding and dietary composition are considered here. 
Many early experiments to elucidate nutritional effects on reproduction in the pig used full- and limited-feeding systems as the basis for the studies. This means that the dietary regimes compared contained different levels of both energy and protein. Therefore, this work must be considered separately from the more recent investigations of energy and protein effects which have employed isonitrogenous and isoenergetic diets respectively.

The results available from these studies are both variable and conflicting. Several workers have reported that full feeding of prepubertal gilts results in the early attainment of puberty when compared with their restricted-fed counterparts (Burger, 1952; Zimmerman et al., 1960; Goode, Warnick and Wallace, 1965; Friend, 1974; 1976). However, other results suggest that puberty attainment is either unaffected by plane of feeding (Robertson et al., 1951b; Christian and Nofziger, 1952; Lodge and MacPherson, 1961, Pay and Davies, 1973) or is delayed by full feeding (Self, Grummer and Casida, 1955; Hafez, 1960; MacPherson, Hovell and Jones, 1977). These results are summarized in Table 6.1.

Table 6.1 THE EFFECTS OF PLANE OF NUTRITION ON PUBERTY ATTAINMENT IN GILTS

\begin{tabular}{lll}
\hline Age at puberty & (days) & Source \\
High plane diet & Low plane diet & \\
\hline 198 & 203 & Robertson et al. (1951b) \\
188 & 235 & Burger (1952) \\
170 & 167 & Christian and Nofziger (1952) \\
223 & 208 & Self et al. (1955) \\
195 & 217 & Haines et al. (1959) \\
212 & 182 & Hafez (1960) \\
195 & 205 & Zimmerman et al. (1960) \\
178 & 176 & Lodge and MacPherson (1961) \\
262 & 292 & Goode et al. (1965) \\
189 & 187 & Pay and Davies (1973) \\
184 & 201 & Friend (1974) \\
173 & 194 & Friend (1976) \\
203 & 186 & MacPherson al. (1977) \\
\hline
\end{tabular}

The fact that significant results have been obtained to show that high plane feeding can both stimulate and inhibit puberty attainment suggests that other factors may also have been involved to confound the results. Indeed, both breed and seasonal effects are apparent in several of the experiments (e.g. Zimmerman et al., 1960). More importantly, many of the experiments used boars for oestrus detection, hence introducing a further stimulatory influence (e.g. Robertson et al., 1951b; Christian and Nofziger, 1952; Self, Grummer and Casida, 1955; Haines, Warnick and Wallace, 1959; Zimmerman et al., 1960; Goode, Warnick and Wallace, 1965; Pay and Davies, 1973; MacPherson, Hovell and Jones, 1977). Since breed, season and boar contact are all known to influence puberty attainment, the interpretation of the above results must be questioned. Until such time as the interactions between plane of nutrition and these other stimulatory influences are understood no definite conclusion can be reached on the effects of feed level on puberty attainment in gilts. 


\section{Energy intake}

The relationship between energy intake and puberty attainment in the gilt has been extensively reviewed by Anderson and Melampy (1972) and, more recently, by Hughes and Varley (1980). It was apparent in 1972 that no definite relationship between the two factors could be established on the basis of the available data. Indeed, Anderson and Melampy (1972) concluded from 14 experiments that restricted energy intake delayed puberty by an average of 16 days in nine experiments, whereas the restricted diet hastened the onset of puberty by 11 days in five other experiments (see Table 6.2).

Table 6.2 THE EFFECTS OF ENERGY INTAKE ON PUBERTY ATTAINMENT IN GILTS

\begin{tabular}{lllllll}
\hline Number of trials & \multicolumn{2}{c}{$\begin{array}{c}\text { ME intake } \\
\text { (MJ/day) }\end{array}$} & \multicolumn{2}{c}{$\begin{array}{c}\text { Pubertal age } \\
\text { (days) }\end{array}$} & \multicolumn{2}{c}{$\begin{array}{c}\text { Pubertal bodyweight } \\
\text { (kg) }\end{array}$} \\
& Restricted & Full & Restricted & Full & Restricted & Full \\
\hline 9 & 23.2 & 37.5 & 217 & 201 & 74 & 91 \\
5 & 25.2 & 37.5 & 201 & 212 & 74 & 94 \\
\hline
\end{tabular}

From Anderson and Melampy (1972).

Unfortunately, more recent studies do not clarify the situation. In fact, in four experiments studying the effects of energy intake on puberty attainment in the gilt, three concluded that no influence was apparent (Aherne et al., 1976; Friend, 1977; Friend et al., 1979) whereas the fourth suggested that a high energy intake resulted in a delayed onset of puberty (Etienne and Legault, 1974).

Once again these results are undoubtedly confounded by other stimuli, such as boar contact (Gossett and Sorensen, 1959; Sorensen, Thomas and Gossett, 1961; Friend, 1977; Friend et al., 1979). Equally, factors such as degree of energy restriction, gilt age at the start of restriction, and dietary composition may have influenced the results. Hughes and Varley (1980) suggested that the restricted energy intakes used in many of the above studies were, in fact, adequate for an acceptable rate of growth. On this basis it may be expected that little effect would be seen on puberty attainment until a more severe level of restriction was imposed. Indeed, when Burger (1952) severely restricted energy intake (to $50 \%$ of ad libitum) puberty attainment was delayed by 46 days.

It seems that little progress has been made since Anderson and Melampy reviewed the situation in 1972 . Nevertheless, it is reasonable to assume

- that puberty attainment will not be adversely affected by the levels of dietary energy being fed in practice, providing these contain sufficient energy to ensure an adequate level of liveweight growth.

\section{Fat intake}

Little information is available on the effects of dietary fat on puberty attainment in the gilt. It is generally assumed that fat will exert an influence only through its contribution to the total energy content of the diet. However, Witz and Beeson (1951) have reported that puberty attainment 
is delayed in gilts fed fat-free diets. What remains to be established is whether this effect was due to dietary energy level or to a specific fat requirement by the gilt.

\section{Protein intake}

So far it has been assumed that the variations in gilt age at puberty as a result of plane of feeding were due to variations in energy intake. However, since protein intake would also vary with plane of feeding the effects of protein intake and aminoacid balance on puberty attainment must also be considered.

Several reports show that pubertal age increases when gilts are fed a protein-deficient diet (Davidson, 1930; Baker, 1959; Adams et al., 1960; Cunningham et al., 1974; Wahlstrom and Libal, 1977). On the other hand, minor variations in protein intake, in diets containing conventional levels of protein, do not appear to affect puberty attainment significantly (Friend, 1977; Friend et al., 1979).

Fowler and Robertson (1954) reported that gilts fed protein of animal origin reached puberty significantly earlier than counterparts fed plant protein. This suggests that aminoacid imbalances in the diet may influence puberty attainment. Indeed, more recent evidence substantiates this, dietary supplementation with lysine and methionine reducing gilt age at puberty (Larrson, Nilsson and Olsson, 1966; Friend, 1973).

\section{Vitamin and mineral intake}

The roles of vitamins and minerals in pig reproduction generally, and puberty attainment in particular, have received very little attention. However, it does seem probable that severe restrictions of many vitamins and minerals, including vitamin A (Hughes, 1934), vitamin $B_{12}$ (Johnsen, Moustgaard and Højgaard-Olsen, 1952) and manganese (Plumlee et al., 1956), may delay sexual development.

Overall, it has been suggested that nutrient supply, when sufficient for commercially acceptable growth rates, is unlikely to have any significant influence on puberty attainment in the gilt (Tassell, 1967; Brooks and Cole, 1974).

\section{GENETICS}

Ramirez (1973) states that 'the ontogeny of puberty is genetically determined for each species, but the normal rate of maturation can be altered by the environment and this can modify the stage of development'. This implies that genotype will exert a considerable influence on puberty attainment in gilts, although this influence may be masked by environmental stimuli.

Several workers have detected breed differences in age at puberty in the pig (Phillips and Zeller, 1943; Self, Grummer and Casida, 1955; Etienne 


\section{Factors affecting the natural attainment of puberty in the gilt}

and Legault, 1974; Christenson and Ford, 1979). However, the variability in pubertal age within a breed is considerable, this being cited as a reason why other workers have failed to find significant breed differences (Robertson et al., 1951a,b; Warnick et al., 1951; Zimmerman et al. , 1960) see Table 6.3. This within-breed variability in pubertal age may reflect the effects of other stimulatory influences (e.g. boar contact). Additionally, Christenson and Ford (1979) have concluded that significant breedenvironment interactions may also exist, these only serving to further confound the situation. Thus, as in previous sections, the conflicting nature of the data prohibits the drawing of useful conclusions.

Table 6.3 THE EFFECTS OF BREED ON PUBERTY ATTAINMENT IN THE GILT

\begin{tabular}{lll}
\hline Source & Breed used & $\begin{array}{l}\text { Age at puberty } \\
\text { (days) }\end{array}$ \\
\hline Robertson et al. (1951a) & Chester White & 203 \\
Robertson et al. (1951b) & $\begin{array}{l}\text { Poland China } \\
\text { Chester White }\end{array}$ & 198 \\
Warnick et al. (1951) & Poland China & 201 \\
Trial 1 & Chester White & 236 \\
Trial 2 & Yorkshire & 243 \\
Self et al. (1955) & Chester White & 259 \\
Trial 1 & Yorkshire & 249 \\
Trial 2 & Chester White & 225 \\
& Poland China & 206 \\
Zimmerman et al. (1960) & Chester White & 211 \\
& Poland China \\
& Chester White & 216 \\
(restricted-fed) & 198 \\
& Poland China \\
(restricted-fed) & 192 \\
& Chester White & \\
(full-fed) & 206 \\
Dyck (1971) & Poland China \\
(full-fed) & 204 \\
Christenson and Ford (1979) & Yorkshire & 199 \\
& Lacombe & 197 \\
& Landrace & 173 \\
& Large White & 211 \\
& Hampshire & 207 \\
& Duroc & 224 \\
& Yorkshire & 221 \\
\hline & &
\end{tabular}

In contrast, heterotic effects on puberty attainment in the gilt have been repeatedly and consistently demonstrated. The data presented in Table 6.4 clearly show that the crossbred gilt attains puberty earlier than its purebred counterpart. Such heterotic effects are not, however, confined to crosses between breeds. Foote et al. (1956), studying Chester.White, Yorkshire and Chester White $\times$ Yorkshire gilts, reported that mean age at puberty was significantly reduced in line-cross gilts when compared with inbred gilts (194 versus 228 days respectively).

Most reproductive traits that show heterosis tend to be of low heritability. Indeed, Reutzel and Sumption (1968) have reported that the heritability of pubertal age is low or zero, when assessed on a paternal half-sib 
Table 6.4 THE DIFFERENCE IN PUBERTAL AGE BETWEEN PUREBRED AND CROSSBRED GILTS

\begin{tabular}{|c|c|c|c|}
\hline Source & Breed of sire & Breed of dam & $\begin{array}{l}\text { Difference in pubertal age } \\
\text { between crossbred gilts and } \\
\text { their purebred counterparts } \\
\text { (days) }\end{array}$ \\
\hline \multirow[t]{2}{*}{ Warnick es al. (1951) } & $\begin{array}{l}\text { Trial 1: } \\
\text { Chester White }\end{array}$ & Yorkshire & -4 \\
\hline & $\begin{array}{l}\text { Trial 2: } \\
\text { Chester White }\end{array}$ & Yorkshire & -3 \\
\hline Foote ef al. (1956) & $\begin{array}{l}\text { Poland China } \\
\text { Poland China } \\
\text { Duroc }\end{array}$ & $\begin{array}{l}\text { Duroc } \\
\text { Yorkshire } \\
\text { Yorkshire }\end{array}$ & $\begin{array}{l}-11 \\
-32 \\
-36\end{array}$ \\
\hline Short et al. (1963) & $\begin{array}{l}\text { Duroc } \\
\text { Yorkshire }\end{array}$ & $\begin{array}{l}\text { Yorkshire } \\
\text { Duroc }\end{array}$ & $\begin{array}{l}-10 \\
-5\end{array}$ \\
\hline Clark et al. (1970) & $\begin{array}{l}\text { Poland China } \\
\text { Yorkshire }\end{array}$ & $\begin{array}{l}\text { Yorkshire } \\
\text { Poland China }\end{array}$ & $\begin{array}{l}-24 \\
-6 \\
\end{array}$ \\
\hline
\end{tabular}

analysis. However, these workers did obtain a heritability estimate of 0.49 when a daughter-dam regression was used. Such data may reflect a dam effect on the pubertal age of offspring. Other workers have also noted family effects (Burger, 1952) and, particularly, sire effects on gilt age at puberty (Reddy, Lasley and Mayer, 1958; Short, 1963; Hughes and Cole, 1975). Hence, while a reliable figure for the heritability of pubertal age is not available, there would appear to be some genetic basis for selection of this trait.

\section{CLIMATIC ENVIRONMENT}

Although the domestic pig does not have a specific breeding season, it is derived from a seasonally breeding animal and might therefore be expected to show variations in fertility with time of year.

Many reports suggest that season of birth exerts a marked effect on puberty attainment in the gilt. Unfortunately, many of these data are conflicting (Table 6.5), some reports indicating that autumn-born gilts reach puberty earlier than their spring-born counterparts (Wiggins, Casida and Grummer, 1950; Gossett and Sorensen, 1959; Mavrogenis and Robison, 1976) while others indicate the reverse (Sorensen, Thomas and

Table 6.5 THE EFFECTS OF SEASON OF BIRTH ON PUBERTY ATTAINMENT IN THE GILT

\begin{tabular}{lccc}
\hline Source & No. of gilts & \multicolumn{2}{c}{$\begin{array}{c}\text { Age at puberty } \\
\text { (days) }\end{array}$} \\
& & Spring-born & Autumn-born \\
\hline Gossett and Sorensen (1959) & 52 & 216 & 206 \\
Zimmerman et al. (1960) & 71 & 196 & 208 \\
$\quad$ Trial 1 & 60 & 203 & 190 \\
$\quad$ Trial 2 & 98 & 210 & 208 \\
Sorensen et al. (1961) & 153 & 237 & 202 \\
Mavrogenis and Robison (1976) & & &
\end{tabular}




\section{Factors affecting the natural attainment of puberty in the gilt}

Gossett, 1961; Scanlon and Krishnamurthy, 1974). Other studies have either failed to observe seasonal differences at all (Wise and Robertson, 1953; Self, Grummer and Casida, 1955; Christenson and Ford, 1979), found significant differences in one year but not the next (Warnick et al., 1951), or found significant differences in only one of two breeds (Zimmerman et al., 1960) Such inconsistent results must, once again, be reflections of stimulatory influences other than those associated with season. Thus, although it might be expected that spring-born gilts would mature earlier, as did their wild ancestors (Signoret, 1980), there is little evidence to substantiate this. Additionally, it is not clear that puberty attainment in the wild gilt is in response to seasonal changes, since boar contact is also initiated in the autumn.

Table 6.6 THE EFFECTS OF PHOTOPERIOD ON PUBERTY ATTAINMENT IN THE GILT

\begin{tabular}{|c|c|c|c|}
\hline Source & No. of gilts & Lighting regime & $\begin{array}{l}\text { Age at } \\
\text { puberty } \\
\text { (days) }\end{array}$ \\
\hline Dufour and Bernard (1968) & - & $\begin{array}{l}\text { complete darkness } \\
\text { natural photoperiod }\end{array}$ & $\begin{array}{l}208 \\
219\end{array}$ \\
\hline Hacker et al. (1974) & $\begin{array}{l}16 \\
16\end{array}$ & $\begin{array}{l}\text { complete darkness } \\
12 \text { hours light :12 hours dark }\end{array}$ & $\begin{array}{l}222 \\
183\end{array}$ \\
\hline Hacker et al. (1976) & $\begin{array}{l}16 \\
16\end{array}$ & $\begin{array}{l}6 \text { hours light : } 18 \text { hours dark } \\
18 \text { hours light : } 6 \text { hours dark }\end{array}$ & $\begin{array}{l}232 \\
190\end{array}$ \\
\hline \multirow[t]{2}{*}{ Hacker et al. (1979) } & $\begin{array}{l}6 \\
6\end{array}$ & $\begin{array}{l}\text { complete darkness } \\
\text { natural photoperiod } \\
(9.0-10.8 \text { hours light per day })\end{array}$ & $\begin{array}{l}200 \\
165\end{array}$ \\
\hline & 6 & 18 hours light : 6 hours dark & 175 \\
\hline \multirow[t]{2}{*}{ Ntunde et al. (1979) } & $\begin{array}{l}12 \\
12\end{array}$ & $\begin{array}{l}\text { complete darkness } \\
\text { natural photoperiod }\end{array}$ & 193 \\
\hline & 12 & (9.0-10.8 hours light per day) & 176 \\
\hline
\end{tabular}

Seasonal differences will reflect changes in both photoperiod and temperature. It is therefore worthwile to consider the effects of these two factors in isolation. Most studies (Table 6.6) on photoperiod demonstrate that increasing daylength advances the onset of puberty in gilts (Martinat $e t$ al., 1970; Surmuhin and Ceremnyh, 1970; Surmuhin et al., 1970; Hacker, King and Bearss, 1974; Hacker, King and Smith, 1976; Hacker et al., 1979; Ntunde, Hacker and King, 1979). The one conflicting report is that of Dufour and Bernard (1968) who found that gilts reared in complete darkness reached puberty earlier than those reared in normal daylength. While this result agrees with data from other species (e.g. Zacharias and Wurtman, 1964), the rearing of gilts in complete darkness is an abnormal situation that is likely to yield abnormal results. Thus, it may be concluded that long daylengths will be conducive to the early maturation of gilts. The actual optimum light:dark schedule has not been elucidated, although the available data (Klotchkov, Klotchkova, Kim and Belyaev, 1971; Hacker, King and Smith, 1976: Hacker et al., 1979; Ntunde, Hacker and King, 1979) does indicate that 17-18 hours light/day should be sufficient.

The effects of temperature on puberty attainment in gilts are less well documented. High environmental temperatures have been reported to exert an adverse influence on several aspects of reproduction in pigs 
(Corteel, Signoret and Du Mesnil du Buisson, 1964; Edwards et al., 1968; Teague, Roller and Griffo, 1968; Love, 1978), with limited evidence indicating that this may also be true for puberty attainment (Schmidt and Bretschneider, 1954; Stickney et al., 1978). Conversely, Dyck (1974) has observed that the rearing of gilts under conditions of low environmental temperatures has no adverse influence on the attainment of puberty. It may be concluded that moderately low environmental temperatures will facilitate the early attainment of puberty in the gilt. However, it is also worth applying a note of caution, since work with other species has indicated that both very high and very low temperatures may delay the attainment of sexual maturity (Mandl and Zuckerman, 1952; Donovan and van der Werff ten Bosch, 1965).

When the data on photoperiod and temperature are combined to provide seasonal effects it is not surprising that variations in pubertal age are not consistent. Spring-born gilts will be stimulated to reach puberty early by the increasing daylength, but will be inhibited by high environmental temperatures. Conversely, autumn-born gilts will be stimulated by lower temperatures but inhibited by short daylengths. Thus, the actual location of the experimental site (together with the environmental control of the building, where applicable), and hence the actual temperatures and photoperiod experienced by the gilts, will, to a large extent, determine the response obtained.

\section{SOCIAL ENVIRONMENT}

It has long been known that 'stress' factors may both stimulate and inhibit puberty attainment in rodents, the response being dependent on the type and level of 'stress' applied (Duckett, Varon and Christian, 1963; Morton, Denenberg and Zarrow, 1963). In the gilt there is also limited evidence to indicate that some forms of 'stress' may stimulate the early attainment of puberty.

Table 6.7 THE EFFECTS OF STOCKING DENSITY ON PUBERTY ATTAINMENT IN THE GILT

\begin{tabular}{lccl}
\hline Source & No. of gilts & No. of gilts/pen & $\begin{array}{l}\text { Age at puberty } \\
\text { (days) }\end{array}$ \\
\hline Jensen et al. $(1970)^{(\mathrm{a})}$ & - & 1 & 260 \\
& & $5-7$ & 262 \\
Robison (1974) & 15 & $6-10$ & 261 \\
& 30 & 1 & 225 \\
Mavrogenis and Robison (1976) & 50 & 30 & 216 \\
Ford and Teague (1978) ${ }^{(\mathrm{b})}$ & 103 & 1 & 222 \\
& 32 & 8 & 207 \\
Christenson and Ford (1979) & 96 & 12 & 217 \\
Trial 1 & 31 & 8 & 199 \\
& 48 & 24 & 206 \\
Trial 2 & 32 & 8 & 207 \\
& 46 & 24 & 247 \\
\hline
\end{tabular}

(")Data averaged from three trials

(b) Data from three trials where space restriction was also varied. 
Several workers have reported that the crowding of gilts will stimulate early sexual maturation (Robison, 1974; Mavrogenis and Robison, 1976), although other workers have found no effect (Jensen et al., 1967, 1970; Christenson and Ford, 1979). These data are summarized in Table 6.7. What is not clear at present is whether crowding effects, if they exist, are mediated through space restriction (a form of 'stress') or through the presence of many other females (Ford and Teague, 1978).

Undoubtedly, the best known 'stress' factor in pigs is that of transportation. Many workers have reported that transporting prepubertal gilts will result in the precocious attainment of puberty (Du Mesnil du Buisson and Signoret, 1961; Paredis, 1961; Signoret, 1970). However, this stimulus may not be effective until the gilt is very near puberty, since Signoret (1972) reported that only $26.5 \%$ of gilts weighing $90-110 \mathrm{~kg}$ responded to transportation. When this effect is apparent it is clearly independent of boar stimulation since the peak of oestrus occurrence is unaltered when boar exposure is delayed for 10 days after transportation (Signoret, 1970) as shown in Figure 6.1.

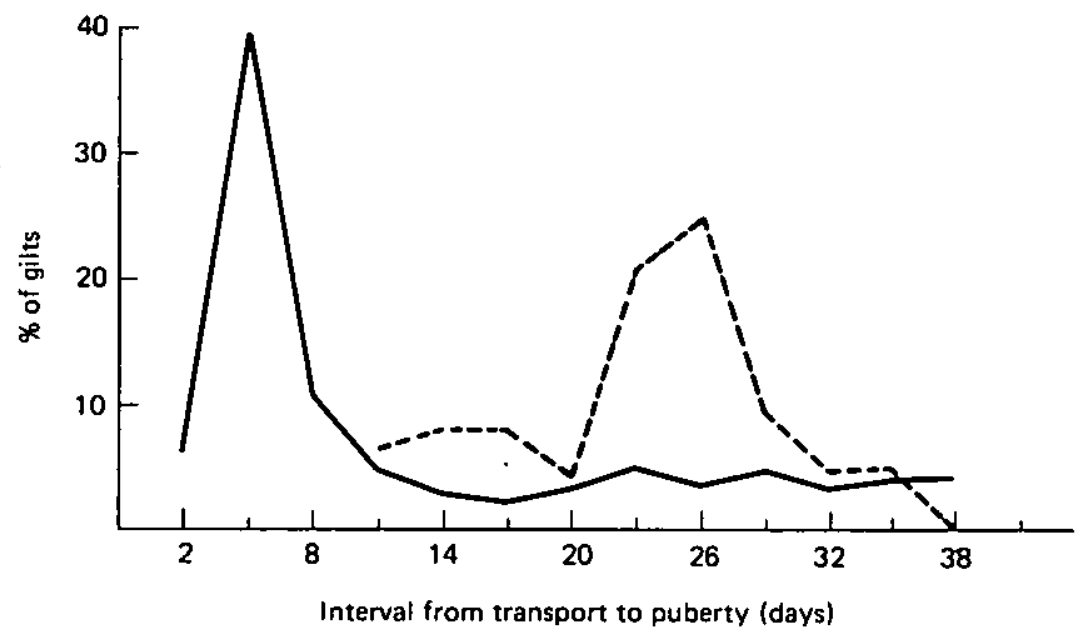

Figure 6.1 The interval between transport and the onset of oestrus in gilts. Dotted line indicates results when presentation to the boar is delayed for 10 days. From Signoret (1970)

The most recent studies in this area have concentrated on the interactions of mixing strange gilts, transportation and relocation, these being tested in the presence or absence of boar contact. The data on these 'management stresses', summarized in Table 6.8 indicate that all these 'stress' factors may have stimulatory effects on puberty attainment in gilts. However, the results presented in Table 6.8 also indicate that boar contact is a more potent form of puberty stimulation than is any form of 'stress'. Finally, it is worth noting that boar contact itself may also include a 'stress' component (Kirkwood, Forbes and Hughes, 1981).

\section{BOAR CONTACT}

It has already been pointed out that contact with a boar will induce puberty attainment in the prepubertal gilt. Indeed, this fact has been repeatedly 


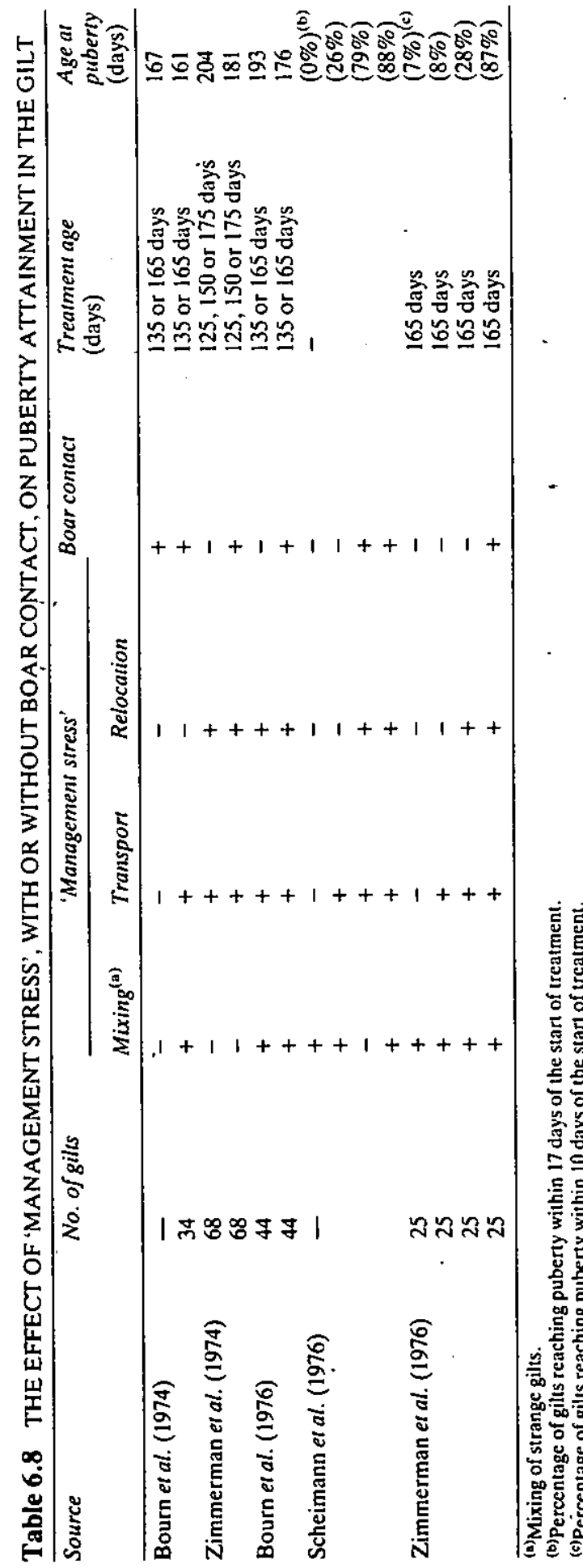


Table 6.9 THE EFFECTS OF GILT AGE AT FIRST BOAR CONTACT ON PUBERTAL AGE AND THE INTERVAL FROM FIRST BOAR CONTACT TO PUBERTY

\begin{tabular}{|c|c|c|c|}
\hline Source & $\begin{array}{l}\text { Gilt age at boar } \\
\text { introduction } \\
\text { (days) }\end{array}$ & $\begin{array}{l}\text { Interval from first boar } \\
\text { contact to puberty } \\
\text { (days) }\end{array}$ & $\begin{array}{l}\text { Age at puberty } \\
\text { (days) }\end{array}$ \\
\hline Zimmerman et al. (1969) & 103 & 67 & 170 \\
\hline Zimmerman et al. (1974) & 125 & 47 & 172 \\
\hline Kirkwood and Hughes (1979) & 125 & 54 & 179 \\
\hline Zimmerman es al. (1969) & 126 & 31 & 157 \\
\hline Kirkwood and Hughes (1979) & 132 & 42 & 174 \\
\hline Bourn et al. (1974) & 135 & 21 & 156 \\
\hline Hughes and Cole (1976) & 135 & 34 & 169 \\
\hline Bourn et al. (1976) & 135 & 40 & 175 \\
\hline Kirkwood and Hughes (1979) & 139 & 27 & 166 \\
\hline Kirkwood and Hughes (1979) & 146 & 21 & 167 \\
\hline Zimmerman et al. (1974) & 150 & 32 & 182 \\
\hline Kirkwood and Hughes (1979) & 153 & 28 & 181 \\
\hline Brooks and Smith (1980) & 160 & 11 & 171 \\
\hline Paterson and Lindsay (1980) & 160 & 15 & 175 \\
\hline Hughes and Cole (1976) & 160 & 18 & 178 \\
\hline Kirkwood and Hughes (1979) & 160 & 19 & 179 \\
\hline Brooks et al. (1969) & 163 & 7 & 170 \\
\hline Brooks and Cole (1970) & 165 & 7 & 172 \\
\hline Bourn et al. (1974) & 165 & 8 & 173 \\
\hline Bourn et al. (1976) & 165 & 13 & 178 \\
\hline Kirkwood and Hughes (1979) & 167 & 12 & 179 \\
\hline Brooks and Cole (1969) & 171 & 21 & 192 \\
\hline Kirkwood and Hughes (1979) & 174 & 24 & 198 \\
\hline Zimmerman et al. (1974) & 175 & 15 & 190 \\
\hline Kirkwood and Hughes (1979) & 181 & 16 & 197 \\
\hline Brooks and Cole (1973) & 183 & 16 & 199 \\
\hline Brooks and Cole (1973) & 188 & 14 & 202 \\
\hline Hughes and Cole (1976) & 190 & 15 & 205 \\
\hline Brooks and Smith (1980) & 200 & 16 & 216 \\
\hline Brooks and Cole (1973) & 215 & 10 & 225 \\
\hline
\end{tabular}

demonstrated by many workers (Brooks and Cole, 1969; 1970; Brooks, Pattinson and Cole, 1969; Robison, 1974; Hughes and Cole, 1976; 1978; Mavrogenis and Robison, 1976; Thompson and Savage, 1978; Kirkwood and Hughes, 1979).

The major factor controlling the efficiency of boar contact as a puberty stimulus is the age of the gilt at the time of boar introduction. This is clearly shown in Table 6.9 and Figures 6.2 and 6.3. When boar contact is initiated at very young gilt ages (3-4 months), pubertal response is minimal and sexual development may possibly be delayed (Zimmerman, Carlson and Nippert, 1969; Brooks and Cole, 1969; Doroshkov, 1974; Hughes and Cole, 1976). This is considered to reflect the relatively young physiological ages of these gilts at the time the stimulus is introduced. Consequently, it has been suggested by Brooks and Cole (1969) that the young gilt may become habituated to the boar stimulus at a stage in development when she is too young to respond. Thus, when the gilt reaches an age when a pubertal response to boar contact might be expected (see below), it is not forthcoming and puberty occurs at a similar age to that of unstimulated gilts. 


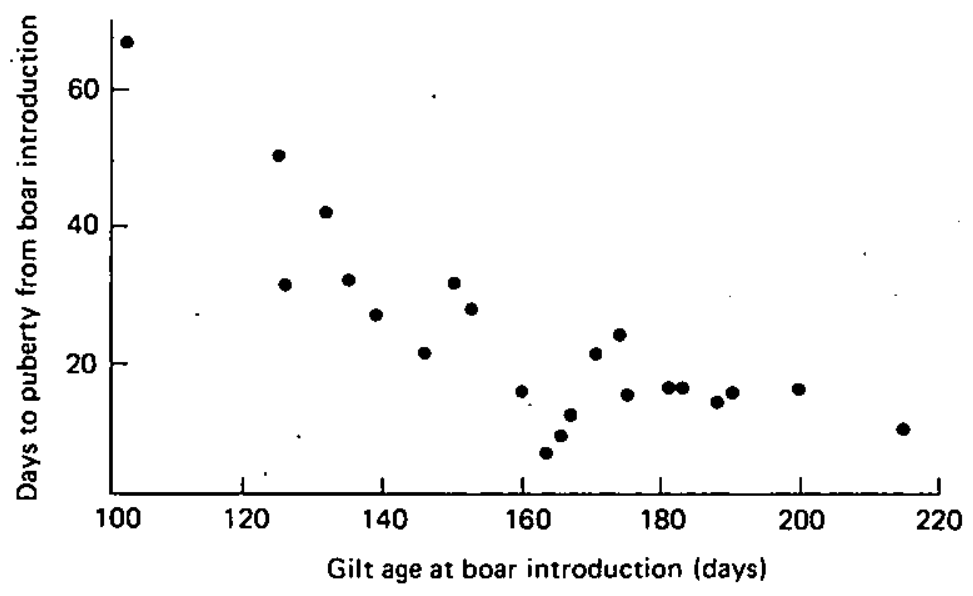

Figure 6.2 The relationship between gilt age at boar introduction and the interval from first boar contact to puberty (data relate to Table 6.9)

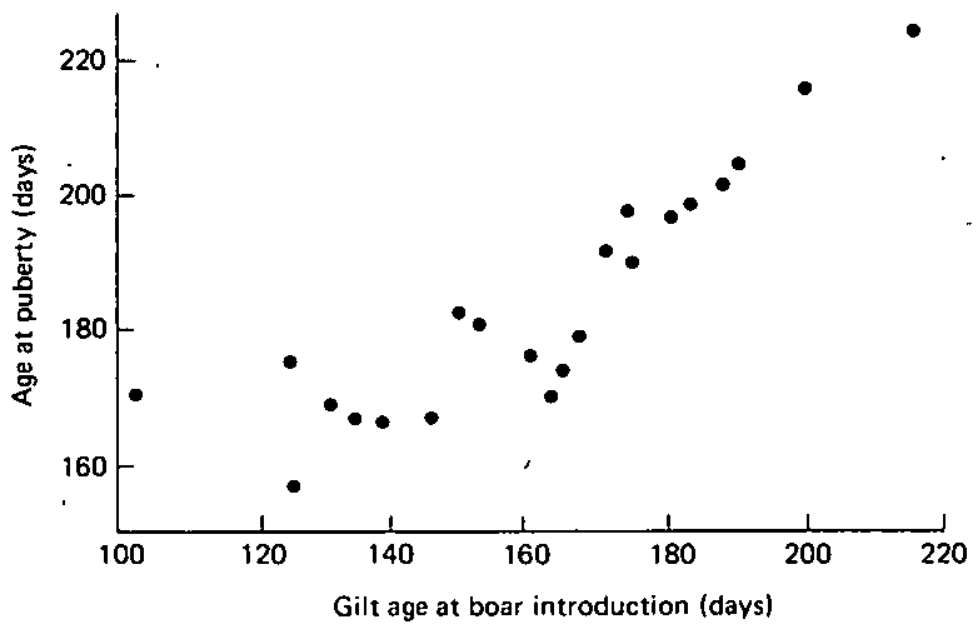

Figure 6.3 The relationship between gilt age at boar introduction and age at puberty (data relate to Table 6.9)

Conversely, when boar introduction is delayed until the immèdiate prepubertal period (six months of age and above) the response is again limited but for a different reason. When boar contact is initiated at these late gilt ages puberty attainment is stimulated, the interval from first boar contact to puberty being similar to that seen in gilts first stimulated at $160-165$ days of age. However, by virtue of the relatively old ages of the gilts at boar introduction; the actual pubertal ages of these gilts are not much reduced below those of unstimulated animals.

While both very young and relatively old gilts demonstrate limited responses to boar contact, gilts first exposed to a boar at 150-170 days of age display a significant precocity in sexual development. Indeed, when boar introduction. occurs at gilt ages in the region of 160 days, both the 
interval from first boar contact to puberty and gilt age at puberty are minimized (Figures 6.2 and 6.3). Additionally, initiating boar contact at this age results in maximum synchronization of the pubertal oestrus (Brooks and Cole, 1970; Hughes and Cole, 1976).

A report by Brooks and Cole (1970) suggested that gilt response to boar introduction at about 160 days of age could be improved by employing a rotation of boars rather than contact with a single boar. However, several confounding factors present in this experiment prohibited the automatic acceptance of this result. Indeed, more recent studies, albeit using limited numbers of animals, have failed to substantiate the earlier claim. The results of these recent experiments (Kirkwood, 1980; Kirkwood and Hughes, 1980a) indicate that neither a rotation of boars nor continuous boar contact improve gilt response above that obtained with single boar contact for 30 minutes/day (Table 6.10).

Table 6.10 THE EFFECTS OF 30 MINUTES/DAY BOAR CONTACT, CONTINUOUS BOAR CONTACT AND ROTATIONAL BOAR CONTACT ON PUBERTY ATTAINMENT IN THE GILT

\begin{tabular}{lllll}
\hline Source & No. of gilts/ & \multicolumn{3}{c}{ Gilt age at puberly (days) } \\
& treatment & 30 min/day & continuous & rotational \\
\hline Kirkwood and Hughes (1980a) & 10 & 199 & 195 & -194 \\
Kirkwood (1980) & 6 & 187 & 183 & 194 \\
\hline
\end{tabular}

All boar contact was initiated at 165 days of age.

The actual mechanism by which boar contact stimulates puberty attainment in gilts has only recently been investigated. It has long been known that, in other species, this 'male effect' is mediated via a primer pheromone (Vandenbergh, 1969), this, in turn, stimulating an endogenous LH (luteinizing hormone) release in the recipient female (Bronson and Desjardins, 1974). In the pig it was unclear whether the male effect was due to a pheromone, or whether other boar stimuli such as 'stress', auditory and visual cues were involved. A recent experiment carried out by Kirkwood, Forbes and Hughes (1981) set out to investigate this problem by considering the ability of boars to stimulate puberty attainment in anosmic gilts. $\mathrm{s}^{\mathrm{N}} \mathrm{w}$ The results of this trial show that boar contact is ineffective in stimulating precocious puberty attainment in gilts that are unable to perceive pheromones (Table 6.11). This implies that the 'boar effect' is mediated via a primer pheromone. It should, however, be recognized that other boaroriginating stimuli may act synergistically with the primer pheromone(s) to produce the complete 'boar effect'.

Table 6.11 THE INFLUENCE OF BOAR CONTACT(") ON PUBERTY ATTAINMENT IN INTACT AND OLFACTORY BULBECTOMIZED GILTS

\begin{tabular}{lll}
\hline Treatment & $\begin{array}{l}\text { Interval from first boar } \\
\text { contact lo puberty } \\
\text { (days) }\end{array}$ & $\begin{array}{l}\text { Age at puberty } \\
\text { (days) }\end{array}$ \\
\hline Control-no boar contact or surgery & 74 & 234 \\
Boar exposure-olfactory bulbectomized & 70 & 230 \\
Boar exposure-sham-operated & 44 & 204 \\
Boar exposure-no surgery & 48 & 208 \\
\hline
\end{tabular}

(a)From 160 days of age.

From Kirkwood, Forbes and Hughes (1981). 
The nature of the boar pheromone responsible for puberty stimulation has yet to be identified. The major free pheromones produced by the boar originate in the submaxillary salivary gland, and this is considered to be the most probable source of the puberty-accelerating pheromone (Booth, 1980; Kirkwood and Hughes, 1980b; Kirkwood, Forbes and Hughes, 1981 ). Indeed, it has been suggested that the active pheromone responsible for puberty induction is $3 \alpha$-androstenol, but this claim remains to be substantiated.

Most reproductively active pheromones produced by the boar are secreted at very low levels in the young boar, and do not rise to adult levels until the boar approaches one year of age (Booth, 1975). It is, therefore, necessary to consider whether the young postpubertal boar is capable of inducing precocious puberty attainment in the gilt. The one small trial that has been conducted on this subject (Table 6.12) indicated that the boar

Table 6.12 THE EFFECT OF EXPOSURE TO BOARS ${ }^{(1)}$ OF DIFFERENT AGES ON PUBERTY ATTAINMENT IN THE GILT

\begin{tabular}{lll}
\hline Treatment & $\begin{array}{l}\text { Interval from first boar } \\
\text { contact to puberty } \\
\text { (days) }\end{array}$ & $\begin{array}{l}\text { Age at puberty } \\
\text { (days) }\end{array}$ \\
\hline Control-no boar exposure & 39 & 203 \\
Exposure to 6.5-month old boar & 42 & 206 \\
Exposure to 11-month old boar & 18 & 182 \\
Exposure to 24-month old boar & 19 & 182 \\
\hline
\end{tabular}

(a) 30 minute daily exposure from an average gilt age of 164 days.

From Kirkwood and Hughes (1981).

may not be able to stimulate puberty attainment in the gilt until he is approximately 9-10 months of age (Kirkwood and Hughes, 1981). Thus, it may be suggested that older boars are used to induce puberty attainment in replacement gilts. Finally, since entire litter brothers would not be stimulatory to their sisters, it seems unlikely that mixed-sex rearing would result in an habituation effect in the gilt-a conclusion supported by the recent work of Nathan and Cole (1981).

\section{Conclusions}

It is apparent from the foregoing discussion that the rate of sexual development in gilts can be modified by many factors. However, it is equally clear that there has been a lack of definitive research to identify the influences of individual stimulatory/inhibitory factors on puberty attainment. The problem arises, in the main, as a result of using boars to detect the occurrence of the pubertal oestrus. Since it has already been demonstrated that boar contact is the single most effective puberty stimulus, it is difficult to assess the true influence of other factors being examined in such experiments. Whilst the boar contact may be applied over all treatments, and hence may be considered as a standard part of the experiment, it will certainly mask the influences of the applied variables (e.g. nutrition, genotype or climatic environment) and may also interact with them to 
confound interpretation. In view of these problems, it has proved necessary to apply a note of caution when interpreting the majority of available data on factors influencing puberty attainment. Indeed, it is suggested that future experiments in this area should, with the exception of those studies aimed at elucidating aspects of the 'boar effect', avoid the use of boars for oestrus detection. It is recognized that such a move would make the detection of oestrus difficult but, equally, it would allow easier interpretation of results. Under such conditions oestrus detection may be carried out using one or more of three available methods. These are:

(a) visual observations of vulval and behavioural changes,

(b) regular blood sampling and the measurement of plasma progesterone concentrations, and

(c) slaughter followed by ovarian examination for the presence of corpora lutea and corpora albicantia.

This system, using all three methods, has been applied to good effect by Hughes and Cole (1978), and has proved to be as effective (if not as simple) a method of oestrus detection as the use of a boar.

Finally, despite the reservations expressed above, it may be concluded that boar contact is the single most effective natural means of stimulating precocious puberty attainment in the gilt. Response to this stimulus may, however, be augmented by the additional imposition of 'social stress'. Under commercial conditions nutritional and climatic influences on sexual development should be minimal in temperate regions, although both are likely to exert adverse influences under sub-tropical and tropical conditions. Lastly, genotype differences may prove to be useful in a selection programme in the future, but, for the present, there is insufficient information available to justify such a programme.

\section{References}

ADAMS, C.R., BECKER, D.E., TERRILL, S.W., NORTON, M.W. and JENSEN, A.H. (1960). Rate of ovulation and implantation in swine as affected by dietary protein. J. Anim. Sci. 19, 1245 (Abstract)

AHERNE, F.X., CHRISTOPHERSON, R.J., THOMPSON, J.R. and HARDIN, R.T. (1976). Factors affecting the onset of puberty, postweaning oestrus and blood hormone levels of Lacombe gilts. Can. J. Anim. Sci. 56, 681-692 ANDERSON, L.L. and MELAMPY, R.M. (1972). Factors affecting ovulation rate in the pig. In Pig Production (D.J.A. Cole, Ed.), pp. 329-366. London Butterworths

BAKER, B. (1959). Effects of changing levels of nutrition on reproduction of gilts. J. Anim. Sci. 18, 1160 (Abstract)

BOOTH, W.D. (1975). Changes with age in the occurrence of $\mathrm{C}_{19}$ steroids in the testis and submaxillary gland of the boar. J. Reprod. Fert. 42, 459-472

BOOTH, W.D. (1980). A study of some major testicular steroids in the pig in relation to their effect on the development of male characteristics in the pre-pubertally castrated boar. J. Reprod. Fert. 59, 155-162

BOURN, P., CARLSON, R., LANTZ, B. and ZIMMERMAN, D.R. (1974). Age at 
puberty in gilts as influenced by age at boar exposure and transport. $J$. Anim. Sci. 39, 987 (Abstract)

BOURN, P., KINSEY, R., CARLSON, R. and ZIMMERMAN, D.A. (1976). Puberty in gilts as influenced by boar exposure and "transport phenomenon". $J$. Anim. Sci. 41, 344 (Abstract)

BRODY, S. (1945). Bioenergetics and Growth. New York, Reinhold BRONSON, F.H. and DESJARDINS, C. (1974). Circulating concentrations of FSH, LH, oestradiol and progesterone associated with acute maleinduced puberty in mice. Endocrinology 94, 1658-1668

BROOKS, P.H. and COLE, D.J.A. (1969). Effect of boar presence on the age at puberty of gilts. Rep. Sch. Agric. Univ. Nott. 74-77

BROOKS, P.H. and COLE, D.J.A. (1970). Effect of the presence of a boar on attainment of puberty in gilts. J. Reprod. Fert. 23, 435-440

BROOKS, P.H. and COLE, D.J.A. (1973). Meat production from gilts which have farrowed. 1. Reproductive performance and food conversion efficiency. Anim. Prod. 17, 305-315

BROOKS, P.H. and COLE, D.J.A. (1974). The effect of nutrition during the growing period and the oestrous cycle on the reproductive performance of the pig. Livest. Prod. Sci. 1, 7-20

BROOKS, P.H., PATTINSON, M.A. and COLE, D.J.A. (1969). Reproduction in the young gilt. Rep. Sch. Agric. Univ. Nott. 65-67

BROOKS, P.H. and SMITH, D.A. (1980). The effect of mating age on the reproductive performance, food utilisation and liveweight change of the female pig. Livest. Prod. Sci. 7, 67-78

BURGER, J.F. (1952). Sex physiology of pigs. Onderstepoort J. vet. Res., Suppl. 2, 41-52

CHRISTENSON, R.K. and FORD, J.J. (1979). Puberty and estrus in confinement-reared gilts. J. Anim. Sci. 49, 743-751

CHRISTIAN, R.E. and NOFZIGER, J.C. (1952). Puberty and other reproductive phenomena in gilts as affected by plane of nutrition. J. Anim. Sci. 11, 789 (Abstract)

CLARK, J.R., FIRST, N.L., CHAPMAN, A.B. and CASIDA, L.E. (1970) Age at puberty in four genetic groups of swine. J. Anim. Sci. 31, 1032 (Abstract)

CORTEEL, J.M., SIGNORET, J.P. and DU MESNIL DU BUISSON, F. (1964). Seasonal variations in the reproduction in the sow and factors favouring temporary anoestrus. 5th Int. Congr. Anim. Reprod. A.I., Trento, 3, 536-540

CUNNINGHAM, P.J., NABER, C.H., ZIMMERMAN, D.R. and PEO, E.R. (1974). Influence of nutritional regime on age at puberty in gilts. J. Anim. Sci. $39,63-67$

DAVIDSON, H.R. (1930). Reproductive disturbances caused by feeding protein-deficient and calcium-deficient rations to breeding pigs. J. agric. Sci., Camb. 20, 233-239

DICKERSON, J.W.T., GRESHAM, G.A. and MCCANCE, R.A. (1964). The effect of undernutrition and rehabilitation on the development of the reproductive organs: pigs. J. Endocr. 29, 111-118

DONOVAN, B.T. and VAN DER WERFF TEN BOSH, J.J. (1965). Physiology of Puberty. Monographs of the Physiological Society No. 15, London, Arnold 
DOROSHKOV. V.B. (1974). Stimulatory effect of males on reproductive performance of female pigs. Anim. Breed Abstr. 42, 3830

DUCKETT, G.E., VARON, H.H. and CHRISTTAN, J.J. (1963). Effects of adrenal androgens on parabiotic mice. Endocrinology 72, 403-409

DUFOUR, J. and BERNARD, C. (1968). Effect of light on the development of market pigs and breeding gilts. Can. J. Anim. Sci. 48, 425-430

DU MESNIL DU BUISSON, F. and SIGNORET, J.P. (1961). Influence des facteurs externes sur le declenchement de la puberte chez la truie. Ann. Zootech. 11, 53-59

DUNCAN, D.L. and LODGE, G.A. (1960). Diet in relation to reproduction and viability of the young. Comm. Bur. Anim. Nutr. Tech. Comm. No. 21

DYCK, G.W. (1971). Puberty, post-weaning estrus and estrus cycle length in . Yorkshire and Lacombe swine. Can. J. Anim. Sci. 51, 135-140

DYCK, G.W. (1974). Effects of a cold environment and growth rate on reproductive efficiency in gilts. Can. J. Anim. Sci. 54, 287-292

EDWARDS, R.L., OMTVEDT, I.T., TURMAN, E.J., STEPHENS, D.F. and MAHONEY, G.W.A. (1968). Reproductive performance of gilts following heat stress prior to breeding and in early gestation. J. Anim. Sci. 27, $1634-1637$

ETIENNE, M. and LEGAULT, C. (1974). Effects of breed and diet on sexual precocity in the sow. Journées de la recherche porcine en France, pp. 52-62. Paris, L'Institut Technique du Porc

FOOTE, W.C., WALDORF, D.P., CHAPMAN, A.B. SELF, H.L., GRUMMER, R.H. and CASIDA, L.E. (1956). Age at puberty of gilts produced by different systems J. Anim. Sci. 15, 959-969

FORD, J.J. and TEAGUE, H.S. (1978). Effect of floor space restriction on age at puberty in gilts and on performance of farrows and gilts. J. Anim. Sci. 47, 828-832

FOWLER, S.H. and ROBERTSON, E.L. (1954). Some effects of source of protein and an antibiotic on reproductive performance of gilts. J. Anim. Sci. 13, 949-954

FRIEND, D.W. (1973). Influence of dietary amino acids on the age at puberty of Yorkshire gilts. J. Anim. Sci. 37, 701-707

FRIEND, D.W. (1974). Pubertal age and composition of uterus in gilts. $J$. Anim. Sci. 39, 975 (Abstract)

FRIEND, D.W. (1976). Nutritional effects on age at puberty and plasma amino acid level in Yorkshire gilts and on chemical composition, nucleic acid, fatty acid and hydroxy proline content of the uterus. J. Anim. Sci. 43, 404-412

FRIEND, D.W. (1977). Effect of dietary energy and protein on age and weight at puberty of gilts. J. Anim. Sci. 44, 601-607

FRIEND, D.W., LARMOND, E., WOLYNETZ, M.S. and PRICE, K.R. (1979). Piglet and pork production from gilts bred at puberty: chemical composition of the carcass and assessment of meat quality. J. Anim. Sci. 49, 330-341

GOODE, L., WARNICK, A.C. and WALLACE, H.D. (1965). Effect of dietary energy levels upon reproduction and the relation of endometrial phosphatase activity to embryo survival in gilts. J. Anim. Sci. 24, 959-963

GOSSETT, J.W. and SORENSEN, A.M. (1959). The effect of two levels of energy and seasons on reproductive phenomena in gilts. J. Anim. Sci. 18, $40-47$ 
HACKER, R.R., KING, G.J. and BEARSS, W.H. (1974). Effects of complete darkness on growth and reproduction in gilts. J. Anim. Sci. 39, 155 (Abstract)

HACKER, R.R., KING, G.J., NTUNDE, B.N. and NARENDRAN, R. (1979). Plasma estrogen, progesterone and other reproductive responses of gilts to photoperiod. J. Reprod. Fert. 57, 447-451

HACKER, R.R., KING, G.J. and SMITH, V.G. (1976). Effects of 6 and 18 hour light on reproduction in gilts. J. Anim. Sci. 43, 228 (Abstract)

HAFEZ, E.S.E. (1960). Nutrition in relation to reproduction in sows. J. agric. Sci., Camb. 54, 170-178

HAINES, C.E., WARNICK, A.C. and WALLACE, H.D. (1959). The effects of two levels of energy intake on reproductive phenomena in Duroc Jersey gilts. J. Anim. Sci. 18, 347-354

HUGHES, E.H. (1934). Some effects of vitamin A-deficient diets on reproduction of sows. Agric. Res. 49, 943-953

HUGHES, P.E. and COLE, D.J.A. (1975). Reproduction in the gilt. 1. Influence of age and weight at puberty on ovulation rate and embryo survival in the gilt. Anim. Prod. 21, 183-189

HUGHES, P.E. and COLE, D.J.A. (1976). Reproduction in the gilt. 2. Influence of gilt age at boar introduction on the attainment of puberty. Anim. Prod. 23, 89-94

HUGHES, P.E. and COLE, D.J.A. (1978). Reproduction in the gilt. 3. The effect of exogenous oestrogen on the attainment of puberty and subsequent reproductive performance. Anim. Prod. 27, 11-20

HUGHES, P.E. and VARLEY, M.A. (1980). Reproduction in the Pig. London, Butterworths

JENSEN, A.H., GEHRING, M.M., BECKER, D.E. and HARMON, B.G. (1967). Effect of space allowance and tethering on pre- and post-pubertal behaviour of swine. J. Anim. Sci. 26, 1467 (Abstract)

JENSEN, A.H., YEN, J.T., GEHRING, M.M., BAKER, D.H., BECKER, D.E. and HARMON, B.G. (1970). Effects of space restriction and management on pre- and post-pubertal response of female swine. J. Anim. Sci. 31, 745-750

JOHNSEN, H.H.K., MOUSTGAARD, J. and HOJGAARD-OLSEN, N. (1952). The significance of vitamin $\mathrm{B}_{12}$ for the fertility of sows and gilts. Anim. Breed Abstr. 23, 784

KIRKWOOD, R.N. (1980). Puberty in the gilt. PhD Thesis. University of Leeds

KIRKWOOD, R.N., FORBES, J.M. and HUGHES, P.E. (1981). Influence of boar contact on attainment of puberty in gilts after removal of the olfactory bulbs. J. Reprod. Fert. 61, 193-196

KIRKWOOD, R.N. and HUGHES, P.E. (1979). The influence of age at first boar contact on puberty attainment in the gilt. Anim. Prod. 29, 231-238

KIRKWOOD, R.N. and HUGHES, P.E. (1980a). A note on the efficacy of continuous vs limited boar exposure on puberty attainment in the gilt. Anim. Prod. 31, 205-207

KIRKWOOD, R.N. and HUGHES, P.E. (1980b). A note on the influence of 'boar effect' component stimuli on puberty attainment in the gilt. Anim. Prod. 31, 209-211 


\section{Factors affecting the natural attainment of puberty in the gilt}

KIRKWOOD, R.N. and HUGHES, P.E. (1981). A note on the influence of boar age on its ability to advance puberty in gilts. Anim. Prod. 32, 211-214

KLOTCHKOV, D.V., KLOTCHKOVA, A. Ya., KIM, A.A. and BELYAEV, D.K. (1971). The influence of photoperiodic conditions on fertility in gilts. 10th Int. Cong. Anim. Prod., Paris, pp. 1-8

LARSSON, S., NILSSON, T. and OLSSON, B. (1966). Some aspects of the metabolic effect of amino acid supplementation of pig diets. Acta vet. scand. 7, 47-53

LODGE, G.A. and MACPHERSON, R.M. (1961). Level of feeding during early life and the subsequent reproductive performance of sows. Anim. Prod. $3,19-28$

LOVE, R.J. (1978). Definition of a seasonal infertility problem in pigs. Vet. Rec. 103, 443-446

MACPHERSON, R.M., HOVELL, F.D. De B. and JONES, A.S. (1977). Performance of sows first mated at puberty or second or third oestrus and carcass assessment of once bred gilts. Anim. Prod. 24, 333-342

MANDL, A.M. and ZUCKERMAN, S. (1952). Factors influencing the onset of puberty in albino rats. $J$. Endocr. 8, 357-364

MARTINAT, F., LEGAULT, C., DU MESNIL DU BUISSON, F.. OLLIVIER, L. and SIGNORET, J.P. (1970). Retardation of puberty in the sow. In Journées de la recherche porcine en France, pp. 47-54. Paris, L'Institut Technique du Porc

MAVROGENIS, A.P. and ROBISON, O.W. (1976). Factors affecting puberty in swine. J. Anim. Sci. 42, 1251-1255

MONTEIRO, L.S. and FALCONER, D.S. (1966). Compensatory growth and sexual maturity in mice. Anim. Prod. 8, 179-192

MORTON, J.R.C., DENENBERG, V.H. and ZARROW, M.X. (1963). Modification of sexual development through stimulation in infancy. Endocrinology 72, 439-445

NATHAN, S. and COLE, D.J.A. (1981). Boar contact during rearing and attainment of puberty in the gilt. Anim. Prod. 32, 370 (Abstract)

NTUNDE, B.N., HACKER, R.R. and KING, G.J. (1979). Influence of photoperiod on growth, puberty and plasma LH levels in gilts. J. Anim. Sci. 48, 1401-1406

PAREDIS, F. (1961). Investigations on fertility and artificial insemination in the pig. Anim. Breed Abstr. 30, 2697

PATERSON, A.M. and LINDSAY, D.R. (1980). Induction of puberty in gilts. 1. The effects of rearing conditions on reproductive performance and response to mature boars after early puberty. Anim. Prod. 31, 291-297

PAY, M.G. and DAVIES, T.E. (1973). Growth, food consumption and litter production of female pigs mated at puberty and low body weights. Anim. Prod. 17, 85-91

PHILLIPS, R.W. and ZELLER, J.H. (1943). Sexual development in small and large types of swine. Anat. Rec. 85, 387-400

PLUMLEE, M.D., THRASHER, D.M., BEESON, W.W., ANDREWS, F.N. and PARKER, H.E. (1956). The effects of manganese deficiency upon the growth, development and reproduction of swine. J. Anim. Sci. 15, 352-367

RAMIREZ, V.D. (1973). Endocrinology of puberty. In Handbook of Physiology (S.R. Geiger, Ed.), Section 7, Endocrinology, Vol. II, Part 1, pp. 1-28. Washington, D.C., American Physiological Society 
REDDY, V.B., LASLEY, J.F. and MAYER, D.T. (1958). Genetic aspects of reproduction in swine. Res. Bull. Mo. agric. Exp. Stn. No. 666

REUTZEL, L.F. and SUMPTION, L.J. (1968). Genetic and phenotypic relationships involving age at puberty and growth rate in gilts. J. Anim. Sci. 27, 27-30

ROBERTSON, G.L., CASIDA, L.E., GRUMMER, R.H. and CHAPMAN, A.B. (1951a). Some feeding and management factors affecting age at puberty and related phenomena in Chester White and Poland China gilts. $J$. Anim. Sci. 10, 841-866

ROBERTSON, G.L., GRUMMER, R.H., CASIDA, L.E. and CHAPMAN, A.B. (1951b). Age at puberty and related phenomena in outbred Chester White and Poland China gilts. J. Anim. Sci. 10, 647-656

ROBISON, O.W. (1974). Effects of boar presence and group size on age at puberty in gilts. J. Anim. Sci. 39, 224 (Abstract)

SCANLON, P.F. and KRISHNAMURTHY, S. (1974). Puberty attainment in slaughter weight gilts in relation to month examined. J. Anim. Sci. 39, 160 (Abstract)

SCHEIMANN, C.A., ENGLAND, D.C. and KENNICK, W.H. (1976). Initiating estrus in pre-pubertal confinement gilts. J. Anim. Sci. 43, 210 (Abstract)

SCHMIDT, K. and BRETSCHNEIDER, W. (1954). The outward course of the sexual cycle in the sow. Anim. Breed. Abstr. 32, 1046

SELF, H.L., GRUMMER, R.H. and CASIDA, L.E. (1955). The effects of various sequences of full and limited feeding on the reproductive phenomena in Chester White and Poland China gilts. J. Anim. Sci. 14, 573-592

SHORT, R.E. (1963). Influence of heterosis and plane of nutrition on reproductive phenomena in gilts. M.S. Thesis. University of Nebraska

SHORT, R.E., ZIMMERMAN, D.R. and SUMPTION, L.J. (1963). Heterotic influence on reproductive performance in swine. J. Anim. Sci. 22, 868 (Abstract)

SIGNORET, J.P. (1970). Reproductive behaviour of pigs. J. Reprod. Fert. Suppl. 11, 105-117

SIGNORET, J.P. (1972). The mating behaviour of the sow. In Pig Production (D.J.A. Cole, Ed.), pp. 295-314. London, Butterworths

SIGNURET, J.P. (1980). Mating behaviour of the pig. In Reviews in Rural Science, IV. Behaviour, (M. Wodzicka-Tomazewska, T.N. Edey and J.J. Lynch, Eds.), pp. 75-78, Australia, Unversity of New England

SORENSEN, A.M., THOMAS, W.B. and GOSSETT, J.W. (1961). A further study on the influence of level of energy intake and season on reproductive performance of gilts. J. Anim. Sci. 20, 347-359

STICKNEY, K., FOXCROFT, G.R., GARSIDE, D.A. and MORTIMER, M.J. (1978). Aspects of oestrogen-induced puberty in the gilt. Anim. Prod. 26, 388-389 (Abstract)

SURMUHIN, A.F. and CEREMNYH, V.D. (1970). The effect of light on the development of the reproductive organs of gilts. Anim. Breed. Abstr. 39, 3687

SURMUHIN, A.F., CEREMNYH, V.D., TIMOFEEV, V.P. and POZNIKOVA, A.A. (1970). Development of gilts subjected to different light regimes. Anim. Breed. Abstr. 39, 3602

TASSELL, R. (1967). The effects of diet on reproduction in pigs, sheep and cattle. Br. vet. J. 123, 170-176 
TEAGUE, H.S., ROLLER, W.L. and GRIFFO, A.P. Jr. (1968). Influence of high temperature and humidity on the reproductive performance of swine. $J$. Anim. Sci. 27, 408-411

THOMPSON, L.H. and SAVAGE, J.s. (1978). Age at puberty and ovulation rate in confinement as influenced by exposure to a boar. J. Anim. Sci. 47, $1141-1144$

VANDENBERGH, J.G. (1969). Male odour accelerates female maturation in mice. Endocrinology 84, 658-660

WAHLSTROM, R.C. and LIBAL, G.W. (1977). Effect of dietary protein during growth and gestation on development and reproductive performance of gilts. J. Anim. Sci. 45, 94-99

WARNICK, A.C., WIGGINS, E.L., CASIDA, L.E., GRUMMER, R.H. and CHAPMAN, A.B. (1951). Variation in puberty phenomena in inbred gilts. J. Anim. Sci. 10, 479-493

WIGGINS, E.L., CASIDA, L.E. and GRUMMER, R.H. (1950). The effect of season of birth on sexual development in gilts. J. Anim. Sci. 9, 277-280

WISE, F.S. and ROBERTSON, G.L. (1953). Some effects of sexual age on reproductive performance in gilts. J. Anim. Sci. 12, 957 (Abstract)

WITZ, W.M. and BEESON, W.M. (1951). The physiological effects of a fat deficient diet on the pig. J. Anim. Sci. 10, 957-959

ZACHARIAS, L. and WURTMAN, R.J. (1964). Blindness: its relation to age of menarche. Science 144, 1154-1155

ZIMMERMAN, D.R., BOURN, P. and DONOVAN, D. (1976). Effect of "transport phenomenon" stimuli and boar exposure on puberty in gilts. J. Anim. Sci. 42, 1362 (Abstract)

ZIMMERMAN, D.R., CARLSON, R. and LANTZ, B. (1974). The influence of exposure to the boar and movement on pubertal development in the gilt. J. Anim. Sci. 39, 230 (Abstract)

ZIMMERMAN, D.R., CARLSON, R. and NIPPERT, L. (1969). Age at puberty in gilts as affected by daily heat checks with a boar. J. Anim. Sci. 29, 203 (Abstract)

ZIMMERMAN, D.R., SPIES, H.G., RIGOR, E.M., SELF H.L. and CASIDA, L.E. (1960). Effects of restricted feeding, crossbreeding and season of birth on age at puberty of swine. J. Anim. Sci. 19, 687-694 